\title{
DEVELOPMENT AND OPTIMIZATION OF ORODISPERSIBLE TABLETS OF CARVEDILOL BY COMBINATION OF SUPER-DISINTEGRANTS ADDITION AND SUBLIMATION TECHNIQUES
}

\author{
VIJAYANAND P. ${ }^{*}$, SRIDEVI P. ${ }^{1}$, BHAGAVAN RAJU M. ${ }^{1}$ \\ ${ }^{1}$ Sri Venkateshwara College of Pharmacy, Madhapur, Hyderabad 500081, India \\ Email: vijay.svcp@gmail.com
}

Received: 14 Apr 2017 Revised and Accepted: 27 May 2017

\begin{abstract}
Objective: Objective of the present research work was to prepare orodispersible tablets of carvedilol (CDL) for dysphagic patients.

Methods: Carvedilol, an anti-hypertensive drug, was chosen as a model drug in this study. Orodispersible tablets of carvedilol were prepared using different super-disintegrating agents such as crospovidone, croscarmellose sodium and sodium starch glycolate at different concentrations. The best formulation was selected based on disintegration and dissolution profile that was further taken for sublimation studies using camphor, menthol and thymol. Drug-excipients interaction studies were carried out by fourier transform infra-red (FTIR) spectrophotometer with pure drug sample and optimized formulation.
\end{abstract}

Results: The orodispersible tablet formulation having 4\% croscarmellose sodium disintegrated in 92 sec. Hence this formulation was considered best formulation and taken further for sublimation studies. A formulation containing $10 \% \mathrm{w} / \mathrm{w}$ of menthol showed disintegration time of 16 sec with more than $96.64 \%$ drug release within $15 \mathrm{~min}$. Menthol leaves the porous structure as it sublimates from the tablet. This might have contributed to the decrease in disintegration time. Hence, this formulation was considered optimized.

Conclusion: From this study, it can be concluded that orodispersible tablets of carvedilol may prove to be more efficacious in the treatment of hypertension particularly in dysphagic patients.

Keywords: Orodispersible tablets, Super-disintegrants, Sublimation, Carvedilol, Anti-hypertensive

(C) 2017 The Authors. Published by Innovare Academic Sciences Pvt Ltd. This is an open access article under the CC BY license (http://creativecommons.org/licenses/by/4.0/) DOI: http://dx.doi.org/10.22159/ijpps.2017v9i7.19161

\section{INTRODUCTION}

Dysphagia is a biomechanical disorder considered as a clinical syndrome. It is defined as "an inability to swallow, or a sensation that solids or liquids do not pass easily from the mouth to the stomach" [1, 3]. From many reported studies it has been estimated that over six million adults have dysphagia [1]. It can occur in all age groups, but the prevalence increases with increase in age $[1,3]$. Other categories that experience problems using conventional dosage forms include are mentally ill, uncooperative and nauseated patients, those with condition of motion sickness, sudden episodes of allergic attack or coughing [2]. Oral conventional formulations such as tablets, capsules and liquids pose difficulty in swallowing, especially in dysphasic patients [3].

Carvedilol (CDL) is an oral, cardioselective $\beta$-receptor blocking agent, primarily used to treat hypertension [4]. It undergoes extensive first-pass hepatic metabolism due to cytochrome P450 2D6 (CYP2D6) enzymes and its oral bioavailability is only $25-35 \%$. Half-life also varies extensively from 7 to $10 \mathrm{~h}$. The recommended daily dose of CDL is $3.125 \mathrm{mg}$. Depending on the blood pressure (BP) of the patient and tolerance, the dose may be increased slowly to a maximum of up to $25 \mathrm{mg}$ daily [5].

There is a need for the suitable dosage form which addresses low bioavailability of CDL and eases the administration to dysphagic patients. This study tries to address the same by formulating novel oral drug delivery systems of CDL in the form of orodispersible tablets to increase its pharmacokinetic profile and ease administration to dysphagic patients.

In this study, we formulated and evaluated orodispersible tablets (ODTs) containing CDL using a combination of two different approaches namely: super-disintegrants addition and sublimation techniques. The prepared formulations were subjected to both pre and post compression parameters and evaluations including FTIR, carrs' index, the angle of repose, hausner ratio, hardness, friability, disintegration time and dissolution. The ODT formulation was optimized based on disintegration time (DT) and dissolution rate.

\section{MATERIALS AND METHODS}

\section{Materials}

Carvedilol was obtained as gift sample from chandra labs, Hyderabad, India. Crospovidone (CP), croscarmellose sodium (CCS), sodium starch glycolate (SSG), microcrystalline cellulose (MCC) and mannitol were purchased from SD fine chemicals ltd, Mumbai, India. Sodium lauryl sulphate (SLS) and aspartame were purchased from standard reagents, Hyderabad, India. Magnesium stearate, camphor, menthol, thymol were purchased from ESSEL fine chem., Mumbai, India. All other ingredients used were of analytical reagent grade.

Methods

Formulation of orodispersible tablets

Orodispersible tablets of CDL were prepared by direct compression method. The details of formulation composition are shown in table 1. Carvedilol, equivalent to $12.5 \mathrm{mg}$ was used in total tablet weight of $200 \mathrm{mg}$. CP, CCS and SSG were used as super-disintegrants, SLS was used as surfactant, mannitol and MCC as diluents, aspartame as a sweetening agent and magnesium stearate as a lubricant. Drug and all the excipients were weighed accurately and passed through sieve \#60 and mixed well. This mixture was transferred to a mortar and grounded for around 10-12 min [6]. The resulting mixture was compressed in single punch compression machine using $7 \mathrm{~mm}$ flat surface punches. Based on the DT and drug release profile, formulation F8 having 4\% of CCS was optimized and further selected for sublimation studies. As shown in table 2, Camphor, menthol and thymol were used as sublimating agents [11]. Prepared tablets were vacuum dried at $60^{\circ} \mathrm{C}$ for $24 \mathrm{~h}$ to facilitate the sublimation [7].

\section{Evaluation orodispersible tablets}

The prepared ODTs were evaluated for various physicochemical parameters. The formulation that was found optimal with superdisintegrants addition technique was further re-formulated using sublimating agents and evaluated. 
Table 1: Formulation of orodispersible tablets of carvedilol using super-disintegrating agents

\begin{tabular}{|c|c|c|c|c|c|c|c|c|c|c|c|c|}
\hline \multirow[t]{2}{*}{ Ingredients (mg) } & \multicolumn{12}{|c|}{ Formulation code } \\
\hline & F1 & F2 & F3 & F4 & F5 & F6 & F7 & F8 & F9 & F10 & F11 & F12 \\
\hline Carvedilol & 12.5 & 12.5 & 12.5 & 12.5 & 12.5 & 12.5 & 12.5 & 12.5 & 12.5 & 12.5 & 12.5 & 12.5 \\
\hline SLS & 1.2 & 1.2 & 1.2 & 1.2 & 1.2 & 1.2 & 1.2 & 1.2 & 1.2 & 1.2 & 1.2 & 1.2 \\
\hline Mannitol & 50 & 50 & 50 & 50 & 50 & 50 & 50 & 50 & 50 & 50 & 50 & 50 \\
\hline $\mathrm{CP}$ & 2 & 4 & 6 & 8 & - & - & - & - & - & - & - & - \\
\hline CCS & - & - & - & - & 2 & 4 & 6 & 8 & - & - & - & - \\
\hline SSG & - & - & - & - & - & - & - & - & 2 & 4 & 6 & 8 \\
\hline MCC & Q. S & Q.S & Q.S & Q. S & Q.S & Q.S & Q. S & Q. S & Q.S & Q.S & Q.S & Q.S \\
\hline Aspartame & 2 & 2 & 2 & 2 & 2 & 2 & 2 & 2 & 2 & 2 & 2 & 2 \\
\hline Magnesium. stearate & 2 & 2 & 2 & 2 & 2 & 2 & 2 & 2 & 2 & 2 & 2 & 2 \\
\hline
\end{tabular}

*Total weight of the tablet was $200 \mathrm{mg}$. CP = Crospovidone, $\mathrm{CCS}=$ Croscaramellose sodium, $\mathrm{SSG}=$ Sodium starch glycolate, $\mathrm{MCC}=\mathrm{Microcrystalline}$ cellulose, SLS-sodium lauryl sulphate.

Table 2: Formulation of orodispersible tablets of carvedilol using sublimating agents

\begin{tabular}{|c|c|c|c|c|c|c|c|c|c|c|c|c|}
\hline \multirow[t]{2}{*}{ Ingredients (mg) } & \multicolumn{12}{|c|}{ Formulation code } \\
\hline & C1 & $\mathrm{C} 2$ & C3 & $\mathrm{C4}$ & M1 & M2 & M3 & M4 & T1 & T2 & T3 & T4 \\
\hline Carvedilol & 12.5 & 12.5 & 12.5 & 12.5 & 12.5 & 12.5 & 12.5 & 12.5 & 12.5 & 12.5 & 12.5 & 12.5 \\
\hline SLS & 1.2 & 1.2 & 1.2 & 1.2 & 1.2 & 1.2 & 1.2 & 1.2 & 1.2 & 1.2 & 1.2 & 1.2 \\
\hline Mannitol & 50 & 50 & 50 & 50 & 50 & 50 & 50 & 50 & 50 & 50 & 50 & 50 \\
\hline CCS & 8 & 8 & 8 & 8 & 8 & 8 & 8 & 8 & 8 & 8 & 8 & 8 \\
\hline Camphor & 5 & 10 & 20 & 30 & - & - & - & - & - & - & - & - \\
\hline Menthol & - & - & - & - & 5 & 10 & 20 & 30 & - & - & - & - \\
\hline Thymol & - & - & - & - & - & - & - & - & 5 & 10 & 20 & 30 \\
\hline MCC & Q.S & Q.S & Q.S & Q.S & Q.S & Q.S & Q. S & Q.S & Q.S & Q.S & Q.S & Q.S \\
\hline Aspartame & 2 & 2 & 2 & 2 & 2 & 2 & 2 & 2 & 2 & 2 & 2 & 2 \\
\hline Magnesium. stearate & 2 & 2 & 2 & 2 & 2 & 2 & 2 & 2 & 2 & 2 & 2 & 2 \\
\hline
\end{tabular}

*Total weight of the tablet was $200 \mathrm{mg}$. CCS = Croscaramellose sodium, MCC = Microcrystalline cellulose, SLS = sodium lauryl sulphate.

\section{Pre and post compression parameters}

Pre-compression parameters (bulk and tapped density, carrs' index, hausner ratio, the angle of repose) and post compression parameters (weight variation, hardness, thickness, friability, Moisture uptake) were determined for the tablet blend and compressed tablets respectively as per pharmacopoeial specifications $[8,9,10,16]$.

\section{In vitro disintegration time}

For disintegration study, a method reported by Kadria et al. was followed (6). Briefly, tablets were placed in a beaker containing $20 \mathrm{ml}$ distilled water at $37 \pm 0.5{ }^{\circ} \mathrm{C}$. Time for complete disintegration of the tablet was measured in triplicate and average values were considered for comparison $[6,17]$.

\section{Drug release studies}

In vitro dissolution of the ODTs was studied using USP XXIV Type II dissolution apparatus (Electrolab, Mumbai, India). A paddle stirrer at $100 \mathrm{rpm}$ and $900 \mathrm{ml}$ of $\mathrm{pH} 6.8$ phosphate buffer maintained at $37 \pm 0.5$ ${ }^{\circ} \mathrm{C}$ as dissolution medium was used [11]. Aliquots $(5 \mathrm{ml}$ each) were withdrawn at specified time intervals $(2,4,6,8,10,12,14,16,18,20$,
25 and $30 \mathrm{~min}$ ) and replaced with equal volume of fresh medium to maintain the sink condition. The samples were analyzed for drug content using UV-Visible spectrophotometer at $284 \mathrm{~nm}$ [12].

\section{FTIR studies}

FTIR studies were performed to find any possible drug-excipient interaction by $\mathrm{KBr}$ pellet method using Perkin-Elmer spectrophotometer, USA (Model-1615). For this study, pure carvedilol, carvedilol optimized formulations were studied. Drug and excipients (1:1) were prepared and co-ground with $\mathrm{KBr}$. The resultant mixture was subjected to FTIR studies. Scans were performed from $400-4000 \mathrm{~cm}^{-1}$ and an average of 40 scans were taken per sample $[13,18]$.

\section{RESULTS AND DISCUSSION}

\section{Pre-compression parameters}

Pre-compression parameters were studied for both blends of ODT formulations prepared using super-disintegrants (CP, CCS, SSG) and sublimating agents (camphor, menthol, thymol). Results are shown in table 3 and 4 below. All the formulations shown adequate flow properties.

Table 3: Pre-compression of formulations prepared using different super-disintegrating agents

\begin{tabular}{|c|c|c|c|c|c|c|}
\hline $\begin{array}{l}\text { Formulation } \\
\text { code }\end{array}$ & $\begin{array}{l}\text { Bulk density } \\
\text { (gm/cc) } \pm S D\end{array}$ & $\begin{array}{l}\text { Tapped density } \\
\text { (gm/cc) } \pm \text { SD }\end{array}$ & $\begin{array}{l}\text { Cars } \\
\text { index } \pm \text { SD }\end{array}$ & $\begin{array}{l}\text { Hausner's } \\
\text { ratio } \pm \text { SD }\end{array}$ & $\begin{array}{l}\text { Angle of Repose } \\
(\theta)\end{array}$ & $\begin{array}{l}\text { Flow } \\
\text { property }\end{array}$ \\
\hline F1 & 0.32 & 0.38 & 12.85 & 1.12 & $32.46^{\circ}$ & Good \\
\hline $\mathrm{F} 2$ & 0.34 & 0.37 & 11.64 & 1.14 & $33.34^{\circ}$ & Good \\
\hline F3 & 0.34 & 0.32 & 12.33 & 1.12 & $25.34^{\circ}$ & Excellent \\
\hline F4 & 0.33 & 0.32 & 13.83 & 1.24 & $27.52^{\circ}$ & Excellent \\
\hline F5 & 0.43 & 0.46 & 11.44 & 1.14 & $32.36^{\circ}$ & Good \\
\hline F6 & 0.36 & 0.42 & 12.52 & 1.14 & $32.34^{\circ}$ & Good \\
\hline F7 & 0.35 & 0.41 & 12.82 & 1.15 & $32.56^{\circ}$ & Good \\
\hline F8 & 0.32 & 0.34 & 13.02 & 1.03 & $28.43^{\circ}$ & Excellent \\
\hline F9 & 0.33 & 0.37 & 14.39 & 1.15 & $33.33^{\circ}$ & Good \\
\hline F10 & 0.32 & 0.34 & 1.51 & 1.06 & $27.44^{\circ}$ & Excellent \\
\hline F11 & 0.44 & 0.52 & 12.60 & 1.17 & $34.22^{\circ}$ & Good \\
\hline F12 & 0.33 & 0.34 & 12.75 & 1.06 & $26.48^{\circ}$ & Excellent \\
\hline
\end{tabular}

$n=3$ 
Table 4: Pre-compression parameters of formulation prepared using sublimating agents

\begin{tabular}{|c|c|c|c|c|c|c|}
\hline Formulation code & $\begin{array}{l}\text { Bulk density } \\
\text { (gm/cc) }\end{array}$ & Tapped density (gm/cc) & Carr's index & Hausner ratio & Angle of repose $(\theta)$ & Flow properties \\
\hline C1 & 0.36 & 0.45 & 12.34 & 1.12 & $28.32^{\circ}$ & Good \\
\hline $\mathrm{C} 2$ & 0.42 & 0.48 & 11.22 & 1.14 & $29.43^{\circ}$ & Good \\
\hline $\mathrm{C} 3$ & 0.32 & 0.34 & 14.51 & 1.22 & $25.43^{\circ}$ & Excellent \\
\hline $\mathrm{C} 4$ & 0.33 & 0.32 & 11.34 & 1.21 & $25.22^{\circ}$ & Excellent \\
\hline M1 & 0.34 & 0.32 & 14.29 & 1.24 & $28.35^{\circ}$ & Excellent \\
\hline M2 & 0.32 & 0.36 & 12.38 & 1.14 & $31.45^{\circ}$ & Good \\
\hline M3 & 0.34 & 0.43 & 14.645 & 1.16 & $32.43^{\circ}$ & Good \\
\hline M4 & 0.34 & 0.32 & 12.29 & 1.04 & $26.42^{\circ}$ & Excellent \\
\hline $\mathrm{T} 1$ & 0.36 & 0.40 & 12.47 & 1.12 & $32.33^{\circ}$ & Good \\
\hline $\mathrm{T} 2$ & 0.36 & 0.42 & 14.45 & 1.14 & $32.52^{\circ}$ & Good \\
\hline T3 & 0.36 & 0.44 & 12.67 & 1.12 & $34.35^{\circ}$ & Good \\
\hline $\mathrm{T} 4$ & 0.34 & 0.36 & 11.40 & 1.02 & $27.16^{\circ}$ & Excellent \\
\hline
\end{tabular}

$n=3$

\section{Post compression properties}

Post compression studies were performed for both ODT formulations prepared using super-disintegrants and sublimating agents. Results are shown in table 5 and 6 . From the data, it is evident that DT for ODT reduce significantly $(\mathrm{P}>0.001)$, when prepared by a sublimation method.

\section{Disintegration time}

Different super-disintegrants were evaluated in the formulation of CDL-ODT. For this purpose, three commonly used superdisintegrants CP, CCS and SSG were used in the formulation of CDLODT and evaluated at four different concentrations $(1,2,3$ and $4 \%$ $\mathrm{w} / \mathrm{w})$. The effect of disintegrant type and their respective concentration is shown in fig. 1. From the fig., it is evident that there is an inverse linear relation between disintegrant concentration used in the formulation and disintegration time. Disintegration time decreased with increase in super-disintegrant concentration.

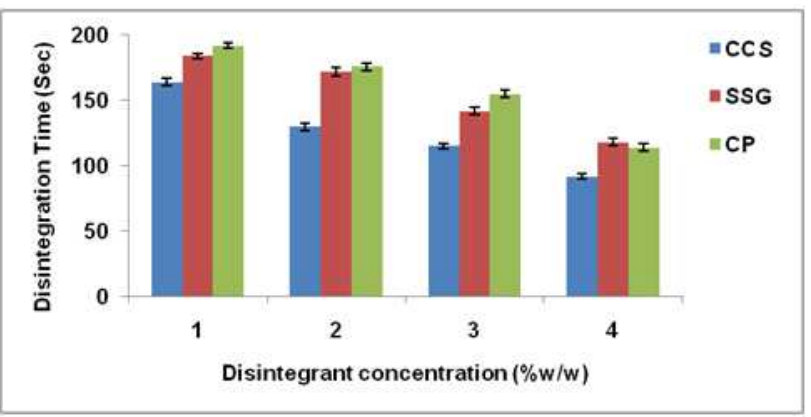

Fig. 1: Comparison of disintegration time of formulations prepared using different super-disintegrants $(n=3$, Mean= $=$ SD)

Based on the data from fig. 1, it is evident that the disintegration time decreased as the concentration of the super-disintegrants increased. Among all the highest concentrations of disintegrants (4 $\% \mathrm{w} / \mathrm{w}$ ), the formulations containing CCS showed lowest mean disintegration time ( $92 \pm 2 \mathrm{sec}, n=3)$ compared to formulations with CP $(114 \pm 3 \mathrm{sec}, n=3)$ and SSG $(118 \pm 3 \mathrm{sec}, n=3)$. It is interesting to note that the DT of the SSG at $4 \% \mathrm{w} / \mathrm{w}$ concentration increased more than CP and CCS.

This may be due to the swell and burst mechanism of disintegration in SSG versus wicking mechanisms in CCS and CP. We understand from the literature that an increase in the concentration of SSG leads to gel-like matrix and this might have hindered disintegration of SSG containing formulation [14]. Therefore, based on this data, the CCS containing formulation was selected for further optimization to achieve a target DT below $30 \mathrm{sec}$ using sublimation technique [15].
In sublimation technique, formulations containing $4 \% \mathrm{w} / \mathrm{w}$ CCS (F8) was re-formulated using commonly used sublimating agents camphor, menthol and thymol at four different concentrations $(2.5,5,10$ and $15 \% \mathrm{w} / \mathrm{w}$ ) and disintegration time was noted (table 6). It was observed that, with increasing concentration of the sublimating agent, there was a linear decrease in disintegration time $\left(r^{2}=0.942\right)$. This decrease could be due to the formation of a porous matrix structure in the tablet. The formulation containing $15 \% \mathrm{w} / \mathrm{w}$ menthol (M4) showed lowest disintegration time $(14 \mathrm{sec})$ but failed in the friability test (1.86\%). A formulation containing $10 \% \mathrm{w} / \mathrm{w}$ of menthol (M3) disintegrated within $16 \mathrm{sec}$ and passed the disintegration test. This formulation (M3) showed drug release of $96.64 \%$ within $15 \mathrm{~min}$ Therefore formulation M3 was considered optimized. The comparison of best-selected formulations of super disintegrant addition and sublimation technique is shown in fig. 2.

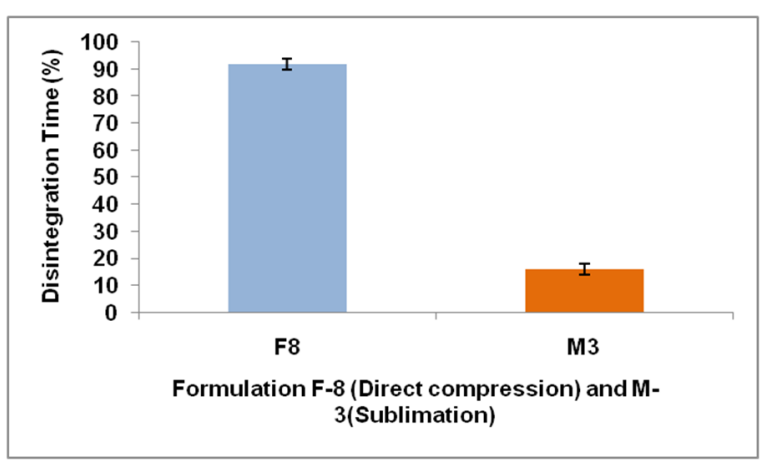

Fig. 2: Comparison of disintegration time of formulations prepared using super-disintegrant (F8) by direct compression and using sublimating agent (M3). (n=3, mean \pm SD)

\section{FTIR studies}

FTIR studies were performed on pure CDL, formulation F8 and optimized formulation (M3). All characteristic peaks of CDL were present in their original positions, denoting the absence of drugexcipient interaction. The FTIR spectra are given in fig. 3 .

\section{Drug dissolution studies}

In vitro drug release data is presented in fig. 4 . From the figure, it is evident that the CDL-ODT formulation (F8) containing $4 \% \mathrm{w} / \mathrm{w}$ CCS dissolved to an extent of $96.65 \%$ within $20 \mathrm{~min}$. The optimized formulation (M3) containing $10 \% \mathrm{w} / \mathrm{w}$ of menthol (with $4 \% \mathrm{w} / \mathrm{w}$ CCS) released $96.64 \%$ of drug within 15 min. The available data was subjected to various mathematical models. The best fit model was found to be first order. The " $\mathrm{r}^{2}$ "value was found to be 0.9882 . Analysis

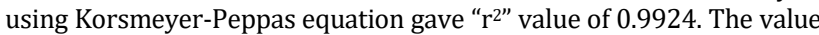
of " $n$ " was found to be 0.46 indicating the drug release followed nonfickian mechanism of drug release. Drug release from the ODT dosage form was by both diffusion as well as dissolution. 
Table 5: Post-compression properties of odts prepared using super-disintegrating agents

\begin{tabular}{|c|c|c|c|c|c|c|c|c|c|c|c|c|}
\hline \multirow[t]{2}{*}{ Parameters } & \multicolumn{12}{|c|}{ Formulation code } \\
\hline & F1 & F2 & F3 & F4 & F5 & F6 & F7 & F8 & F9 & F10 & F11 & F12 \\
\hline $\begin{array}{l}\text { Weight variation } \\
(\mathrm{mg})^{* * *}\end{array}$ & $197 \pm 2$ & $201 \pm 2$ & $202 \pm 3$ & $200 \pm 3$ & $199 \pm 2$ & $196 \pm 3$ & $200 \pm 2$ & $202 \pm 3$ & $199 \pm 2$ & $198 \pm 3$ & $199 \pm 2$ & $201 \pm 3$ \\
\hline Hardness $\left(\mathrm{kg} / \mathrm{cm}^{2}\right)^{*}$ & $5.6 \pm 0.2$ & $5.7 \pm 0.3$ & $5.8 \pm 0.3$ & $5.9 \pm 0.2$ & $5.8 \pm 0.3$ & $5.2 \pm 0.3$ & $5.2 \pm 0.3$ & $5.6 \pm 0.4$ & $5.8 \pm 0.2$ & $6.0 \pm 0.2$ & $6.2 \pm 0.4$ & $6.2 \pm 0.2$ \\
\hline Thickness $(\mathrm{cm})$ & $3.36 \pm 0.6$ & $3.34 \pm 0.12$ & $3.36 \pm 0.08$ & $3.38 \pm 0.4$ & $3.40 \pm 0.06$ & $3.32 \pm 0.1$ & $3.33 \pm 0.06$ & $3.33 \pm 0.06$ & $3.31 \pm 0.1$ & $3.4 \pm 0.08$ & $3.4 \pm 0.08$ & $3.38 \pm 0.1$ \\
\hline Friability (\%)* & $0.2 \pm 20$ & $0.26 \pm 0.1$ & $0.7 \pm 0.01$ & $0.25 \pm 00$ & $0.26 \pm 0.01$ & $0.42 \pm 0.02$ & $0.26 \pm 0.02$ & $0.28 \pm 0.03$ & $0.26 \pm 0.02$ & $0.35 \pm 0.02$ & $0.24 \pm 0.02$ & $0.36 \pm 0.02$ \\
\hline $\begin{array}{l}\text { Disintegration time } \\
\text { (sec)** }\end{array}$ & $192 \pm 2$ & $176 \pm 3$ & $155 \pm 3$ & $114 \pm 3$ & $164 \pm 3$ & $130 \pm 3$ & $115 \pm 2$ & $92 \pm 2$ & $184 \pm 2$ & $172 \pm 3$ & $142 \pm 3$ & $118 \pm 3$ \\
\hline
\end{tabular}

Value are expressed as mean $\pm \mathrm{SD},{ }^{* * *} n=[20],{ }^{* *} n=6,{ }^{*} n=3$

Table 6: Post-compression parameters of odt prepared using sublimating agents after drying

\begin{tabular}{|c|c|c|c|c|c|c|c|c|c|c|c|c|}
\hline \multirow[t]{2}{*}{ Parameters } & \multicolumn{12}{|c|}{ Formulation code } \\
\hline & C1 & $\mathrm{C} 2$ & C3 & C4 & M1 & M2 & M3 & M4 & T1 & T2 & T3 & T4 \\
\hline $\begin{array}{l}\text { Weight variation } \\
(\mathrm{mg})^{* * *}\end{array}$ & $194 \pm 2$ & $188 \pm 2$ & $182 \pm 2$ & $167 \pm 3$ & $188 \pm 4$ & $184 \pm 2$ & $175 \pm 3$ & $172 \pm 4$ & $188 \pm 3$ & $182 \pm 2$ & $172 \pm 4$ & $166 \pm 3$ \\
\hline Hardness $\left(\mathrm{kg} / \mathrm{cm}^{2}\right)^{*}$ & $4.5 \pm 0.3$ & $4.6 \pm 0.2$ & $4.4 \pm 0.3$ & $3.9 \pm 0.2$ & $4.4 \pm 0.2$ & $4.6 \pm 0.3$ & $4.3 \pm 0.3$ & $3.9 \pm 0.2$ & $4.4 \pm 0.3$ & $4.1 \pm 0.2$ & $3.8 \pm 0.3$ & $3.5 \pm 0.2$ \\
\hline Thickness $(\mathrm{cm})$ & $3.24 \pm 0.12$ & $3.26 \pm 0.08$ & $3.36 \pm 0.22$ & $3.36 \pm 0.06$ & $3.26 \pm 0.06$ & $3.37 \pm 0.1$ & $3.32 \pm 0.1$ & $3.36 \pm 0.04$ & $3.46 \pm 0.08$ & $3.38 \pm 0.08$ & $3.28 \pm 0.22$ & $3.40 \pm 0.1$ \\
\hline Friability (\%)* & $0.41 \pm 0.1$ & $0.40 \pm 0.22$ & $0.56 \pm 0.14$ & $0.85 \pm 0.02$ & $0.52 \pm 0.08$ & $0.76 \pm 0.07$ & $0.92 \pm 0.54$ & $1.86 \pm 0.12$ & $0.54 \pm 0.10$ & $0.58 \pm 0.10$ & $0.65 \pm 0.14$ & $1.7 \pm 0.12$ \\
\hline $\begin{array}{l}\text { Disintegration time } \\
\text { (sec)** }\end{array}$ & $50 \pm 2$ & $32 \pm 4$ & $24 \pm 4$ & $18 \pm 4$ & $44 \pm 2$ & $24 \pm 2$ & $16 \pm 2$ & $14 \pm 2$ & $62 \pm 4$ & $46 \pm 5$ & $25 \pm 4$ & $17 \pm 3$ \\
\hline
\end{tabular}

All the values are presented as mean $\pm S D . * * * n=[20],{ }^{* *} n=6,{ }^{*} n=3$

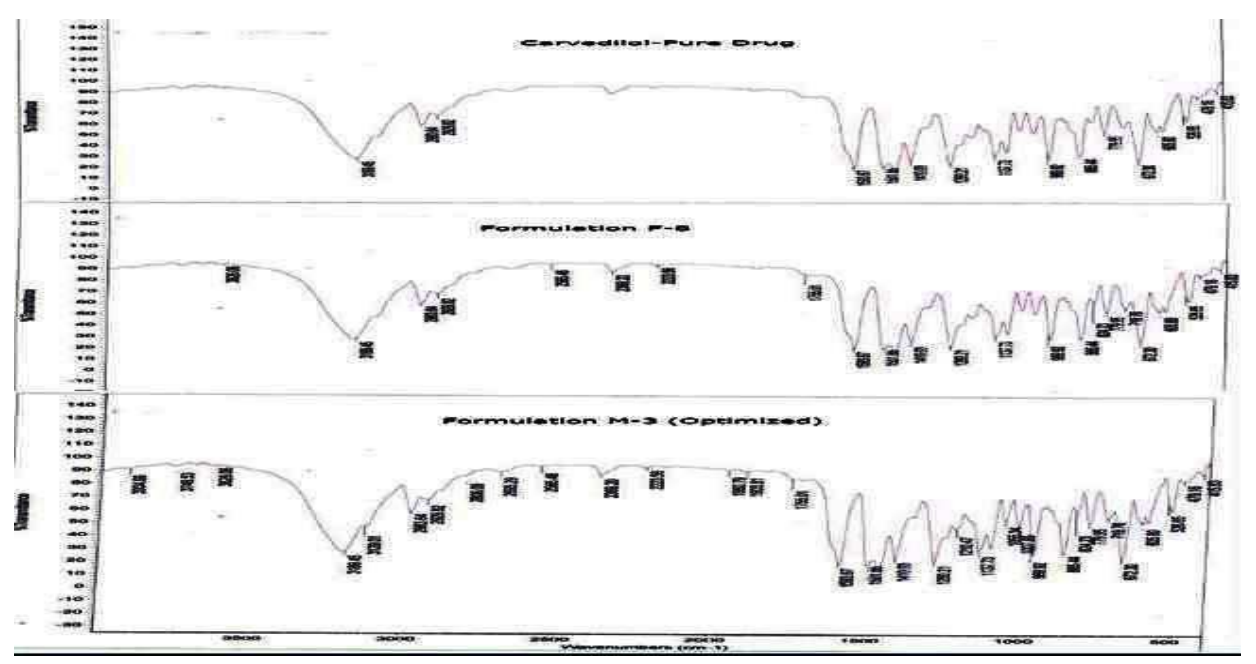

Fig. 3: IR-Spectrum of pure CDL; formulation F8 and Optimized ODT formulation (M3). Scans were performed from $400-4000 \mathrm{~cm}^{-1}$. Average of $40 \mathrm{scans}$ was taken 

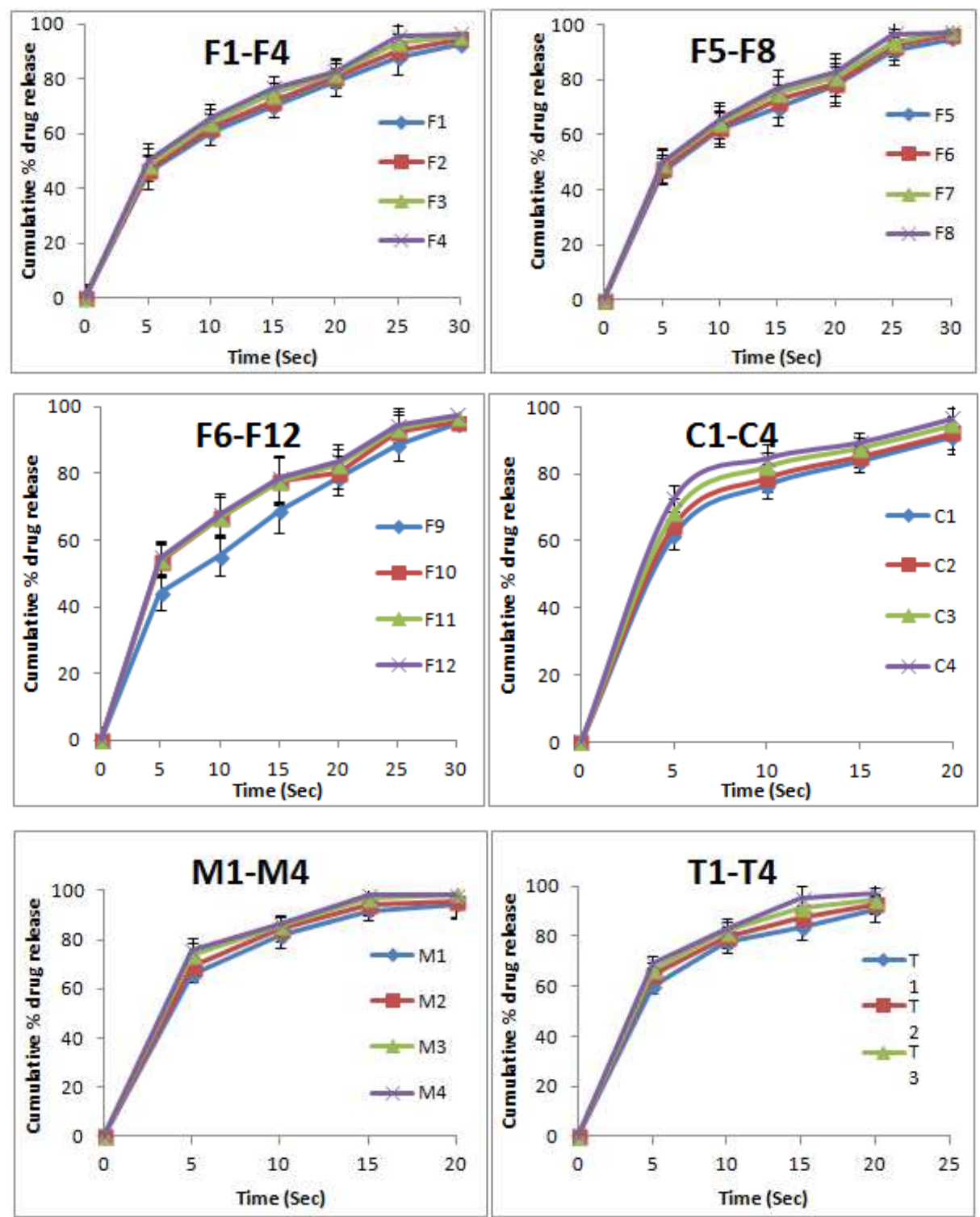

Fig. 4: In vitro drug release profile in pH 6.8 buffer for CDL-ODT formulations containing super-disintegrant F1-F12 and sublimating agents Camphor (C1-C4); Menthol (M1-M4); Thymol (T1-T4). (n=3, mean \pm SD)

\section{CONCLUSION}

In this research work, we have made systematic efforts to formulate orodispersible tablets of Carvedilol using different superdisintegrating agents and sublimating agents. Based upon the DT, the formulation containing 4\% CCS (F8) was selected for sublimation studies. Formulation M3 containing menthol as sublimating agent showed lowest DT and passed friability test. Hence, formulation M3 was considered optimized. Therefore, from this study, it can be concluded that orodispersible tablets of carvedilol may prove to be more efficacious in the treatment of hypertension particularly in dysphagic patients.

\section{ACKNOWLEDGEMENT}

The authors are thankful to Sri Venkateshwara College of Pharmacy, Madhapur, Hyderabad, for constant support and encouragement to complete this research work.

\section{AUTHORS CONTRIBUTION}

Dr Vijayanand P performed the practical work. Dr Sridevi P assisted in the preparation of the manuscript. Dr. M Bhagavan Raju supervised the research work.

\section{CONFLICTS OF INTERESTS}

All authors have none to declare

\section{REFERENCES}

1. Guidance for Medication Assessment in Patients with Swallowing (Dysphagia) or Feeding Disorders Pharmacy Benefits Management-Strategic Healthcare Group (PBM); 2006. Available from: http://www.pbm.va.gov/ clinicalguidance/ clinicalrecommendations/ Dysphagia RecommendationsforMedicationAssessment. pdf. [Last accessed on 09 Aug 2016].

2. Punit BP, Rakshit CP, Dharmik MM, Pragna KS, Bhavesh SB. Quick dissolving films of nebivolol hydrochloride: formulation and optimization by a simplex lattice design. J Pharm Investign 2013:43:343-51.

3. Dixit AS, Parthasarathi KK, Hosakote GS. Gels and jellies as a dosage form for dysphagia patients: a review. Curr Drug Ther 2011;6:79-86.

4. COREG ® [package insert]. NC: GlaxoSmithKline; 2015.

5. https://www.medicines.org.uk/emc/PIL.28229.latest.pdf. [Last accessed on 04 Nov 2016]. 
6. Kadria AE, Hassan MA, Afifi SA. Formulation and optimization of orodispersible tablets of flutamide. Saudi Pharm J 2014;22:53-61.

7. Sasidhar RC, Vidyadhara S, Deepti B, Nagaraju R, Satish KR. Formulation and optimization of orodispersible tablets containing an antidepressant. Pharm Lett 2014;6:156-64.

8. Aulton ME, Wells TI. Pharmaceutics: The science of dosage form design. Churchill Livingstone, London, England; 1998. p. 247-9.

9. Lachman L, Lieberman HA, Kanig JL. The theory and practice of industrial pharmacy. $3^{\text {rd }}$ Ed. Varghese Publishing House, Mumbai; 1987. p. 293-9.

10. USP, NF. Asian edition, United States Pharmacopoeia Convention Inc; 2000. p. 1913-4.

11. Shirsand SB, Suresh S, Kusumdevi V, Swamy PV. Formulation design and optimization of fast dissolving clonazepam tablets by a sublimation method. Indian J Pharm Sci 2011;73:491-6.

12. Shinkar DM, Dhake AS, Setty CM. Development of UV spectrophotometric method for estimation of carvedilol in bulk and pharmaceutical formulations. Asian J Res Chem 2013;6:956-9.

13. Punna Rao R, Aditya N, Himanshu K, Srinivas M, Rahul V. Lipid nanoparticles for oral delivery of raloxifene: optimization, stability, in vivo evaluation and uptake mechanism. Eur J Pharm Biopharm 2014;87:114-24.

14. Bala R, Khanna S, Pawar P. Polymers in the fast disintegrating tablet a review. Asian J Pharm Clin Res 2011;5:8-14.
15. Guidance for Industry Orally Disintegrating Tablets. U. S. department of health and human services food and drug administration center for drug evaluation and research (CDER); 2008. Available from: http://www.fda.gov/downloads/Drugs/ GuidanceComplianceRegulatoryInformation/Guidances/ucm070 578.pdf [Last accessed on 2016 Aug 12].

16. Ashok T, Veeravalli SK, Pavan KM, Roshitha B. Effect of effervescence in combination with super disintegrants in the formulation of propranolol HCL oral disintegrating tablets. Asian J Pharm Clin Res 2017;10:227-34.

17. Shivangi S, Navneet Verma. Taste masked orodispersible tablets: a highly patient complaint dosage form. Asian J Pharm Clin Res 2016;9:385-91.

18. Seema K, Megha S, Abhisek P. Ethylcellulose floating microspheres of antidiabetic agent: in vitro and in vivo evaluation. Int J Appl Pharm 2017;9:44-9.

\section{How to cite this article}

- Vijayanand P, Sridevi P, Bhagavan Raju M. Development and optimization of orodispersible tablets of carvedilol by a combination of super-disintegrants addition and sublimation techniques. Int J Pharm Pharm Sci 2017;9(7):155-160. 